\title{
Hornbeam pollen in the air of Poland in 2018
}

\author{
Małgorzata Puc ${ }^{1,2}$, Daniel Kotrych ${ }^{3}$, Krystyna Piotrowska-Weryszko ${ }^{4}$, Elżbieta Weryszko-Chmielewska ${ }^{4}$, \\ Agnieszka Lipiec ${ }^{5}$, Grzegorz Siergiejko ${ }^{6}$, Małgorzata Malkiewicz ${ }^{7}$, Katarzyna Dąbrowska-Zapart ${ }^{8}$, \\ Kazimiera Chłopek ${ }^{8}$, Monika Ziemianin ${ }^{9}$, Artur Górecki ${ }^{10}$, Dariusz Jurkiewicz ${ }^{11}$, \\ Agnieszka Świdnicka-Siergiejk0 ${ }^{12}$, Adam Rapiejk0 ${ }^{13,14}$, Kornel Szczygielski" ${ }^{11}$, Ewa Kalinowska ${ }^{13}$, \\ Piotr Rapiejko"11, Alina Stacewicz',2 \\ ${ }^{1}$ Department of Botany and Nature Conservation, Faculty of Biology, University of Szczecin, Poland \\ ${ }^{2}$ Molecular Biology and Biotechnology Centre, Faculty of Biology, University of Szczecin, Poland \\ ${ }^{3}$ Department of Orthopedics and Traumatology, Pomeranian Medical University of Szczecin, Poland \\ ${ }^{4}$ Department of Botany, University of Life Sciences in Lublin, Poland \\ ${ }^{5}$ Department of Prevention of Environmental Hazards and Allergology, Medical University of Warsaw, Poland \\ ${ }^{6}$ Pediatrics, Gastroenterology and Allergology Department, University Children Hospital, \\ Medical University of Bialystok, Poland \\ ${ }^{7}$ Department of Palaeobotany, Institute of Geological Sciences, University of Wroclaw \\ ${ }^{8}$ Department of Paleontology and Stratigraphy, Faculty of Earth Sciences, University of Silesia \\ ${ }^{9}$ Department of Clinical and Environmental Allergology, Jagiellonian University, Medical College \\ ${ }^{10}$ Institute of Botany, Jagiellonian University \\ ${ }^{11}$ Department of Otolaryngology with Division of Cranio-Maxillo-Facial Surgery in Military Institute of Medicine, \\ Warsaw, Poland \\ ${ }^{12}$ Department of Gastroenterology and Internal Medicine, Medical University of Bialystok \\ ${ }^{13}$ Allergen Research Center, Poland \\ ${ }^{14}$ Oxford Archaeology Ltd., Oxford, England
}

Abstract: The study compares the hornbeam pollen seasons in Bialystok, Bydgoszcz, Drawsko Pomorskie, Zielona Gora, Opole, Sosnowiec, Cracow, Piotrkow Trybunalski, Warsaw, Lublin, Olsztyn and Szczecin in 2018. The investigations were carried out using the volumetric method (Hirst type pollen sampler). Seasonal Pollen Index was estimated as the sum of daily average pollen concentrations in the given season. Pollen season was defined as the period in which $98 \%$ of the annual total catch occurred. The pollen season of hornbeam started first in Bialystok, on the April $3^{\text {rd }}$. At the latest, a pollen season ended in Lublin and Sosnowiec at the beginning of May. However, in most other cities the season lasted till the end of April. The differences of pollen seasons duration were considerable, from 16 to 36 days. The highest airborne concentration of 168 pollen grains $/ \mathrm{m}^{3}$ was noted in Lublin on the April $14^{\text {th }}$. The maximum values of seasonal pollen count occurred between April $12^{\text {th }}$ and $16^{\text {th }}$. The highest hornbeam pollen allergen hazard occurred in 2018 in Lublin, Warsaw and Piotrkow Trybunalski.

Key words: aeroallergens, pollen count, hornbeam (Carpinus), 2018

lowering of hornbeam (Carpinus spp.) occurs generally simultaneously with birch allergens. While birch pollen is known as the major tree-allergen in central and northern Europe, the quantitative and qualitative role of hornbeam pollen in allergy has not been evaluated. The pollen from hornbeam is moderately allergenic and cross-reactive with the pollen of birch and alder trees as well as those in the chestnut family. Carpinus pollen count does not usually reach high values, but hornbeam pollen anthesis are of importance in allergology due to occurring cross reactions with food allergens (stone fruit like apple, peach, cherry, nuts - especially hazelnut, almonds, tomatoes, celery, carrots, exotic fruits like avocado, kiwi, lychee, passion fruit and mango) $[1,2]$. 
Only two species of hornbeam occur in Europe: Carpinus betulus and Carpinus orientalis. The range of $C$. orientalis spans across south-eastern Europe. C. betulus is a species common over the greater part of central southern and western Europe. Hornbeam spreads into anthropogenic scrub communities on banks, forest edges or in gorges [3].

In Poland hornbeam usually flowers at the end of April. It is a wind-pollinated tree. Its pollen season is short, usually lasting a few, rarely a dozen days. In successive years the amount of pollen released to the atmosphere is very variable. Compared to other forest trees it is a relatively poor pollen producer. It produces half as much pollen as beech and almost three times less than oak. Carpinus pollen possesses relatively weak aerodynamic features, resulting in it remaining airborne for a relatively short time, which limits its capacity for distant distribution. High air temperature during its flowering period may enable better pollen dispersal by lifting pollen higher into the atmosphere [1].

The symptoms of allergic disease are connected with the concentration of aeroallergen. The threshold value for clinical symptoms for Quercus pollen grains for the many of sensitized patients is visible during exposure to the concentration of 16 pollen grains in $1 \mathrm{~m}^{3}$ of air, while the clinical symptoms for the most of sensitized patients are visible during exposure to the concentration of 91 pollen grains in $1 \mathrm{~m}^{3}$ of air [4].

Aim

The aim of the study was to compare the hornbeam pollen concentrations in the air of Bialystok,
Bydgoszcz, Drawsko Pomorskie, Zielona Gora, Opole, Sosnowiec, Cracow, Piotrkow Trybunalski, Warsaw, Lublin, Olsztyn and Szczecin in 2018.

\section{Material and method}

Measurements of bioaerosols were carried out in the selected cities of Poland, in Bialystok, Bydgoszcz, Drawsko Pomorskie, Zielona Gora, Opole, Sosnowiec, Cracow, Piotrkow Trybunalski, Warsaw, Lublin, Olsztyn and Szczecin in 2018. Measurements were performed by the volumetric method. The used devices, which are recommended by the International Association for Aerobiology (IAA), take air samples (Burkard and Lanzoni as the Hirst type pollen sampler) in volumes corresponding to average human respiratory parameters.

The duration of the pollen season was determined by the $98 \%$ method [5], assuming that the onset and end of the season were days with recorded $1 \%$ and $99 \%$ of the annual total of pollen grains, respectively.

The total pollen count over this period was expressed by the Seasonal Pollen Index (SPI).

On the basis of literature data, the number of days was determined in which concentrations of pollen of the hazel genus exceed the threshold values of consecutive allergy symptoms' development (tab. 1) [4].

\section{Results and discussion}

In the years 1993-199, research on hypersensitivity of hornbeam pollen was carried out in the Geneva region. Among symptomatic patients during the March-April period, $73.5 \%$ were hypersensi-

Table 1. Characteristics of hornbeam pollen season in 2018.

\begin{tabular}{|c|c|c|c|c|c|c|c|c|c|c|c|c|}
\hline $\begin{array}{l}\text { Features of } \\
\text { pollen season }\end{array}$ & $\begin{array}{l}\text { Bialy- } \\
\text { stok }\end{array}$ & $\begin{array}{l}\text { Byd- } \\
\text { goszcz }\end{array}$ & Cracow & $\begin{array}{l}\text { Drawsko } \\
\text { Pomorskie }\end{array}$ & $\begin{array}{l}\text { Piotrkow } \\
\text { Trybu- } \\
\text { nalski }\end{array}$ & Lublin & Olsztyn & Opole & $\begin{array}{l}\text { Szeze- } \\
\text { cin }\end{array}$ & Warsaw & $\begin{array}{l}\text { Sosno- } \\
\text { wiec }\end{array}$ & $\begin{array}{l}\text { Zielona } \\
\text { Gora }\end{array}$ \\
\hline $\begin{array}{l}\text { Duration of } \\
\text { pollen season } \\
\text { (number of } \\
\text { days) }\end{array}$ & $\begin{array}{l}3.04- \\
21.05 \\
(19)\end{array}$ & $\begin{array}{l}4.04- \\
26.04 \\
(23)\end{array}$ & $\begin{array}{l}\mathbf{5 . 0 4 -} \\
19.04 \\
(15)\end{array}$ & $\begin{array}{l}4.04- \\
28.04 \\
(25)\end{array}$ & $\begin{array}{l}9.04- \\
1.05 \\
(23)\end{array}$ & $\begin{array}{l}4.04- \\
9.05 \\
(36)\end{array}$ & $\begin{array}{l}3.04- \\
27.04 \\
(25)\end{array}$ & $\begin{array}{l}8.04- \\
23.04 \\
(16)\end{array}$ & $\begin{array}{l}3.04- \\
28.04 \\
(26)\end{array}$ & $\begin{array}{l}7.04- \\
22.04 \\
(16)\end{array}$ & $\begin{array}{l}\mathbf{5 . 0 4 -} \\
5.05 \\
(31)\end{array}$ & $\begin{array}{l}7.04- \\
25.04 \\
(19)\end{array}$ \\
\hline $\begin{array}{l}\text { Seasonal } \\
\text { Pollen Index } \\
\text { (total) }\end{array}$ & 227 & 262 & 277 & 304 & 430 & 759 & 505 & 226 & 174 & 451 & 316 & 269 \\
\hline $\begin{array}{l}\text { Peak value and } \\
\text { peak date }\end{array}$ & $\begin{array}{l}77 \\
(16.04)\end{array}$ & $\begin{array}{l}46 \\
(16.04)\end{array}$ & $\begin{array}{l}55 \\
(15.04)\end{array}$ & $\begin{array}{l}47 \\
(15.04)\end{array}$ & $\begin{array}{l}87 \\
(14.04)\end{array}$ & $\begin{array}{l}168 \\
(14.04)\end{array}$ & $\begin{array}{l}89 \\
(15.04)\end{array}$ & $\begin{array}{l}45 \\
(14.04)\end{array}$ & $\begin{array}{l}39 \\
(13.04)\end{array}$ & $\begin{array}{l}89 \\
(14.04)\end{array}$ & $\begin{array}{l}79 \\
(12.04)\end{array}$ & $\begin{array}{l}42 \\
(14.04)\end{array}$ \\
\hline $\begin{array}{l}\text { Days } \geq 16 \mathrm{~g} / \\
\mathrm{m}^{3}[4]^{*}\end{array}$ & 4 & 7 & 5 & 6 & 8 & 8 & 7 & 6 & 4 & 9 & 5 & 7 \\
\hline $\begin{array}{l}\text { Days } \geq 91 \mathrm{~g} / \mathrm{m}^{3} \\
{[4]^{\star \star}}\end{array}$ & 0 & 0 & 0 & 0 & 0 & 3 & 0 & 0 & 0 & 0 & 0 & 0 \\
\hline
\end{tabular}

* symptoms present in many patients; * ${ }^{*}$ symptoms present in most patients. 


\section{MEDIGAL AEROBIOLOGY}

\section{ORIGLAL PAPER}

Figure 1. Hornbeam pollen count in Bialystok and Bydgoszcz in 2018.

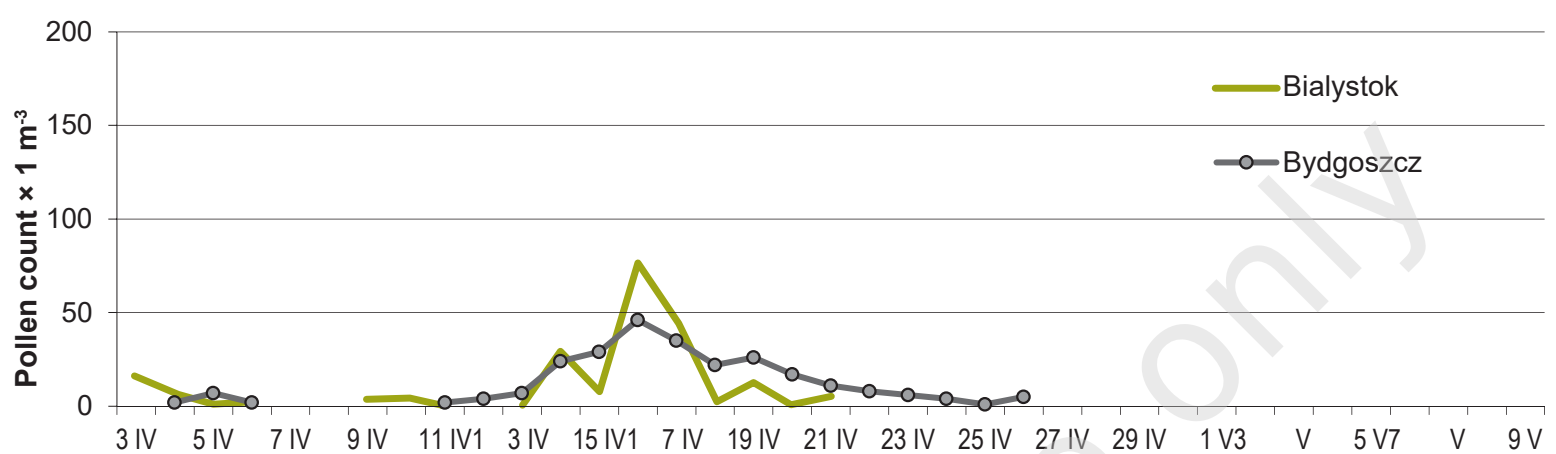

Figure 2. Hornbeam pollen count in Cracow and Drawsko Pomorskie in 2018.

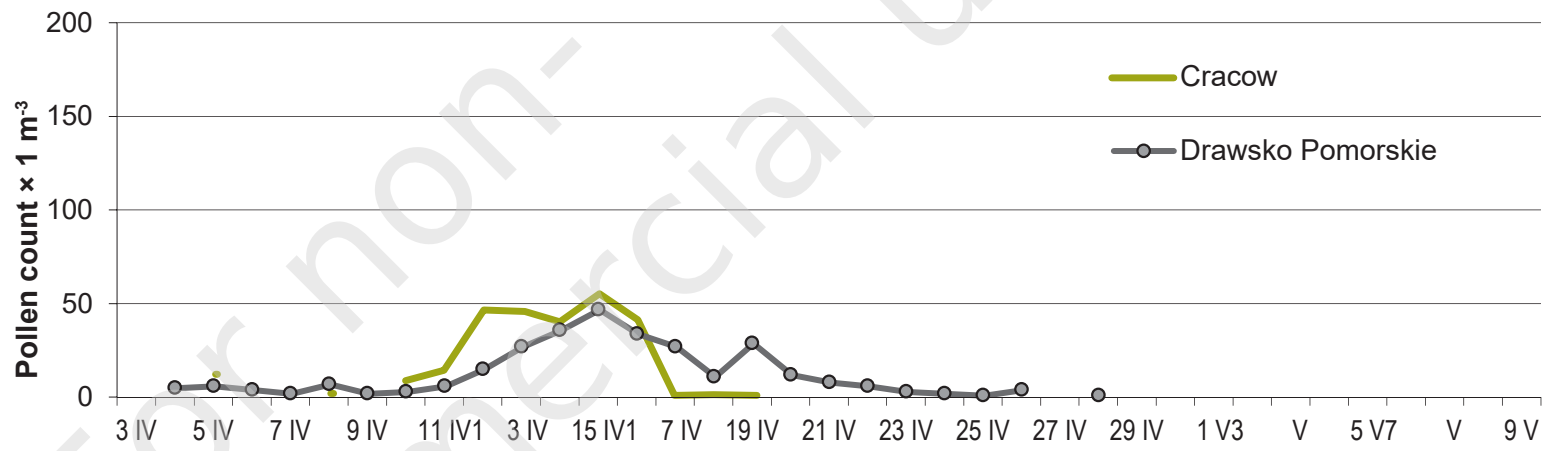

Figure 3. Hornbeam pollen count in Piotrkow Trybunalski and Lublin in 2018.

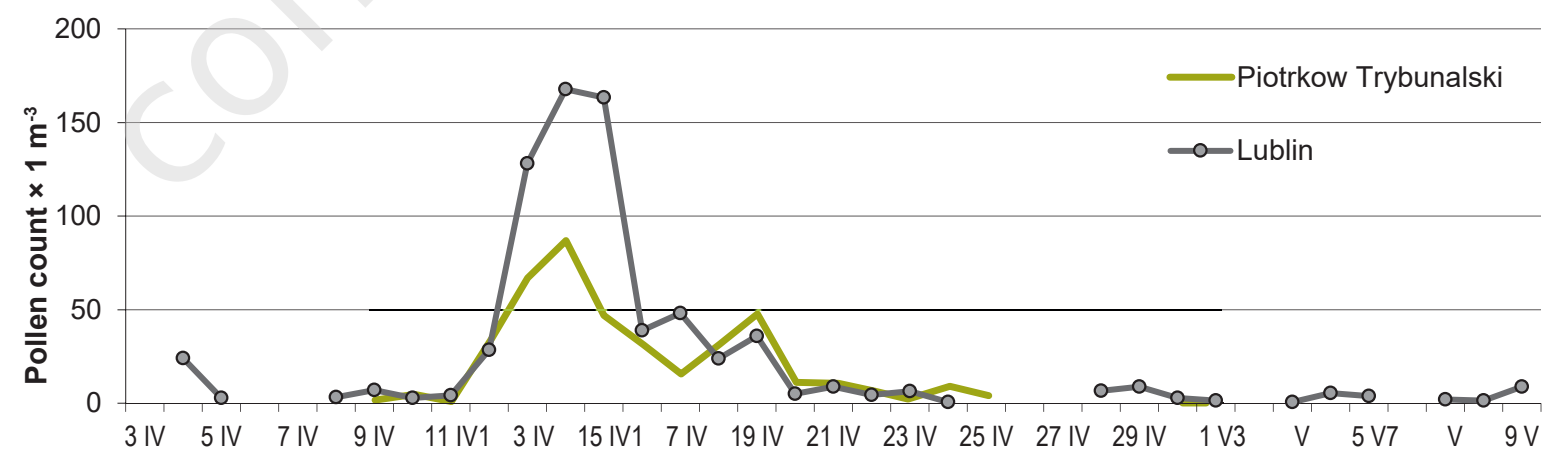

Figure 4. Hornbeam pollen count in Olsztyn and Opole in 2018.

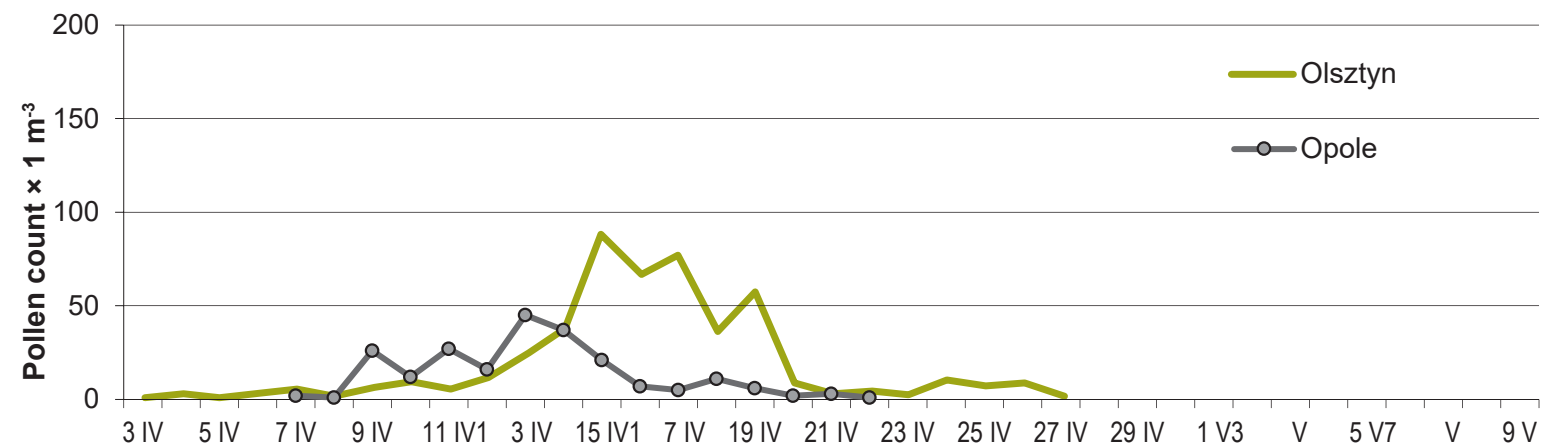


Figure 5. Hornbeam pollen count in Szczecin and Warsaw in 2018.

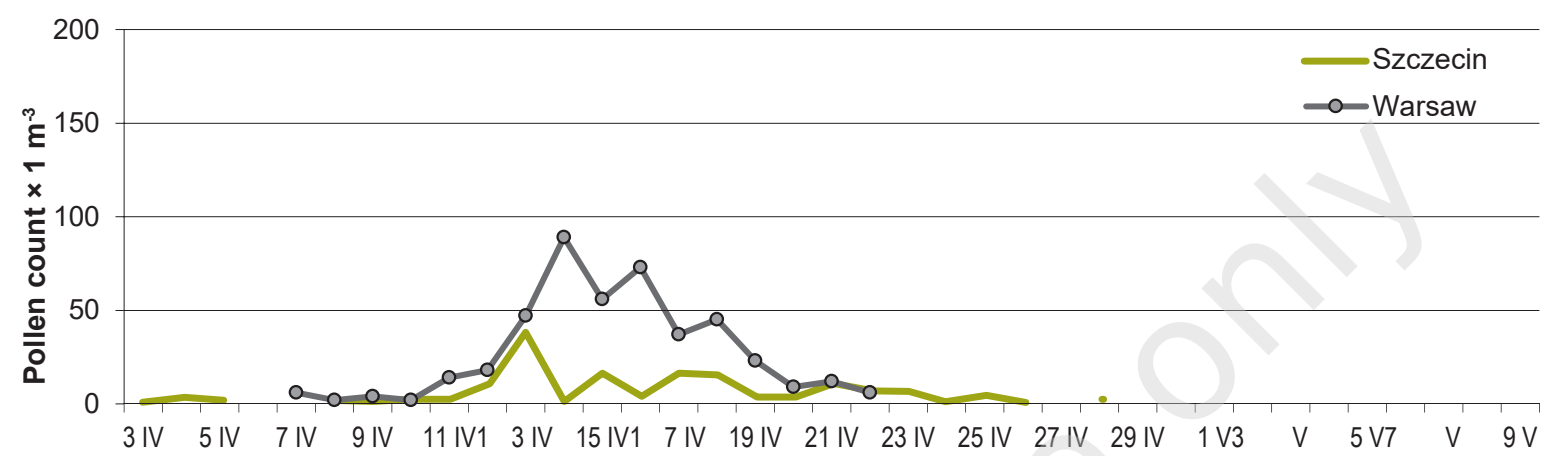

Figure 6. Hornbeam pollen count in Sosnowiec and Zielona Gora in 2018.

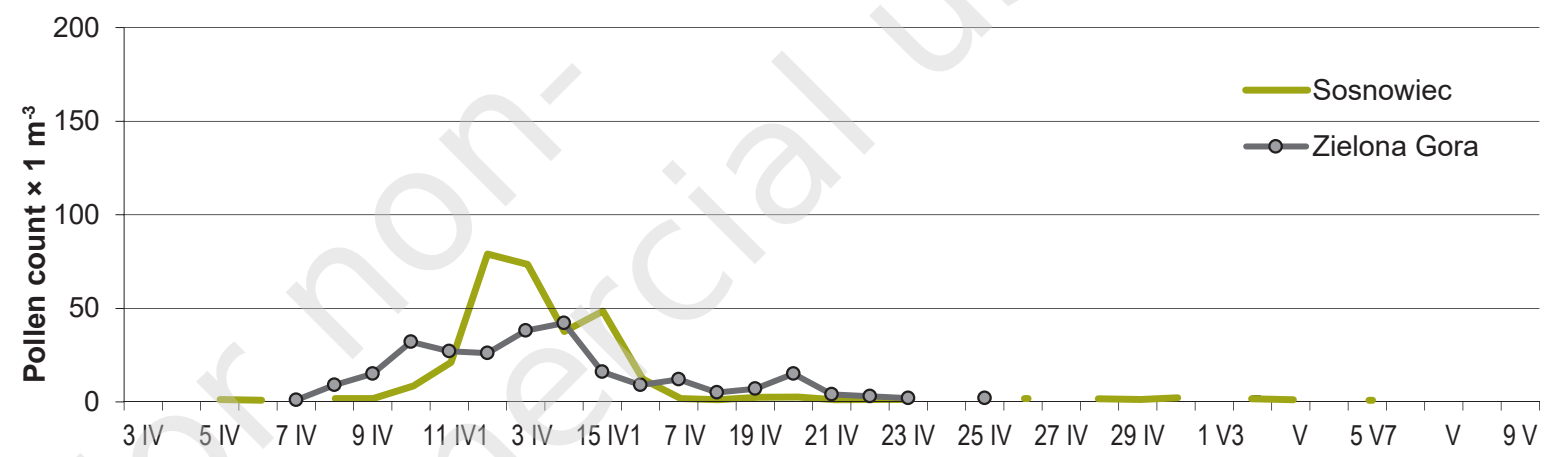

tive to Betulaceae pollen. Overall, $71.7 \%$ of the patients allergic to Betulaceae pollen were found to be sensitive to hornbeam, and $12.5 \%$ of the same group of patients were sensitive to hornbeam pollen only. Among this last group, half of the patients, besides allergic rhino-conjunctivitis, were also suffering from asthma. Hornbeam pollen is abundant and appears to have a significative importance in spring allergies. According to the authors [6], in some cases, specific immunotherapy to hornbeam pollen should perhaps be considered.

In 2018 hornbeam pollen season started between April $3^{\text {rd }}$ and $9^{\text {th }}$ and lasted until the beginning of May. In 2014 the Carpinus pollen season in Polish cities started the earliest on March $20^{\text {th }}$ in Zielona Gora [7], i.e. 2 weeks earlier than in 2018. The hornbeam pollen season started the earliest in Bialystok (tab. 1, fig. 1-6). Comparison of the onset of pollen season in Polish cities in 2014 [7] and 2018 showed a tendency to delay the beginning of the season in 2018 .

The highest daily pollen count of Carpinus was noted in 2018 in Lublin on April 14 ${ }^{\text {th }}\left(168 \mathrm{~g} / \mathrm{m}^{3}\right)$ (tab. 1, fig. 1-6) and the highest annual sum of hornbeam pollen grains (SPI) was observed also in Lublin, a high value was noted also in Olsztyn; in other cities SPI value was much lower (the lowest value in Szczecin was SPI 174). In 2014 the maximum daily concentration was observed on April $7^{\text {th }}$ in Szczecin [7].

The highest Carpinus pollen allergen hazard occurred (above $91 \mathrm{~g} / \mathrm{m}^{3}$ ) in Lublin (only 3 days). In other cities that value has not been recorded.The comparison of hornbeam pollen seasons in previous years revealed that in 2014 [7] pollen of this taxon concentrations was much lower, in Szczecin $38 \mathrm{~g} / \mathrm{m}^{3}$, and the number of days with the highest allergen hazard did not exceed 4 days.

The severity of inhalant allergy symptoms is also related to the degree of air pollution. Research regarding the effects of traffic air pollution and hornbeam pollen on adult asthma hospitalizations [8] suggest that traffic-related air pollution is associated with increased risk of adult asthma hospitalization. Nonetheless, the most significant risk for asthma hospitalization is associated with hornbeam pollen levels in the city of Zagreb. Such a threat may also occur in Polish cities, especially with high air pollution.

\section{Conclusions}

Hornbeam pollen season in most cities was 40-56 days long and was characterized by different total annual pollen SPI (from 174 to 759 ). 
The start of Carpinus pollen season in 2018 occurred in the beginning of April and the end of pollen season was noted in the end of April; only in Lublin and Sosnowiec the hornbeam pollen season lasted until the beginning of May.

The highest hornbeam pollen allergen hazard occurred in 2018 in Warsaw, Piotrkow Trybunalski and Lublin $\left(\geq 16 \mathrm{~g} / \mathrm{m}^{3}\right)$, while the period with pollen counts exceeding the threshold value $\left(\geq 91 \mathrm{~g} / \mathrm{m}^{3}\right.$ ) lasted only 3 days in Lublin.

The concentration of hornbeam pollen is higher when there are many local sources of pollen with many species within the genus Carpinus.

\section{References}

1. Kaplan I, Holt P, Bousquet J, Kay A. Grass, tree, and weed pollen. Allergy and Allergic Diseases 2009, 2(1): 954-958.

2. D'Amato G, Spieksma FTM, Bonini S (eds). Allergenic Pollen and Pollinosis in Europe. Blackwell Scientific Publ 1991.

3. Faliński JB, Pawlaczyk P. Outline of ecology. In: Białobok S (ed). Grab zwyczajny Carpinus betulus L. Nasze drzewa leśne. Monografie popularnonaukowe 9. Sorus, PoznańKórnik 1993: 157-263.

4. Burge HA. Monitoring for airborne allergens. Ann Allergy 1992, 69: 9-21.

5. Emberlin $J$, Savage $M$, Woodman $R$. Annual variations in the concentrations of Betula pollen in the Lon- don area 1961-1990. Grana 1993, 32: 359-363. DOI: 10.1080/00173139309428965.

6. Gumowski PI, Clot B, Davet A et al. The importance of hornbeam (Carpinus sp.) pollen hypersensitivity in spring allergies. Aerobiologia 2000, 16(1): 83-86.

7. Lipiec A, Puc M, Kalinowska E et al. Pylek grabu w powietrzu wybranych miast Polski w 2014 r. Alergoprofil 2014, 10(3): 48-53.

8. Krmpotic D, Luzar-Stiffler V, Rakusic N et al. Effects of traffic air pollution and hornbeam pollen on adult asthma hospitalizations in Zagreb. Int Arch Allergy Immunol 2011, 156(1): 62-68. DOI: 10.1159/000322177.

Authors' contributions:

Puc M: 40\%; Kotrych D: 10\%; Lipiec A: 10\%; Stacewicz A: 10\%; and other Authors: 2,2\% each.

Conflict of interests: The authors declare that they have no competing interests.

Financial support: Does not occur.

Ethics: The contents presented in this paper are compatible with the rules the Declaration of Helsinki, EU directives and standardized requirements for medical journals.

Research in Bialystok, Bydgoszcz, Olsztyn, Piotrkow Trybunalski, Drawsko Pomorskie, Wroclaw, Zielona Gora and Warsaw funded by Allergen Research Center Ltd. (Ośrodek Badania Alergenów Środowiskowych Sp. z 0.o.).

\section{Corresponding author:}

\section{Malgorzata Puc, PhD, Ass. Prof.}

Department of Botany and Nature Conservation, Faculty of Biology, University of Szczecin 71-412 Szczecin, Z. Felczaka 3c street e-mail: malgorzata.puc@usz.edu.pl 